Jurnal Indonesia Sosial Teknologi: p-ISSN: 2723 - 6609

e-ISSN : 2745-5254

Vol. 2, No. 2 Februari 2021

\title{
MONITORING DAN ALARM JUMLAH PENUMPANG PADA ANGKUTAN UMUM
}

\author{
Mochamad Ravi Adia Pramesti, Muhamad Rafi Abdul Rasyd, Refki Rizki Alfani, \\ Muharammi Dzaki Pasya Sundava, Ghita Putrie Ghantina dan Muhammad Hasbi \\ Ash Shiddieqy \\ Politeknik Negeri Bandung, Indonesia \\ Email: mochamad.ravi.tele418@polban.ac.id,muhamad.rafi.mpem419@polban.ac.id, \\ refki.rizki.mpem419@polban.ac.id,muharammi.dzaki.tele418@ polban.ac.id. \\ ghita.putrie.mpem419@polban.ac.id,m.hasbi.toi18@polban.ac.id
}

\begin{abstract}
One of the current problems in the world is the Covid-19 epidemic. No exception in Indonesia, which is also affected by the virus both socially, namely we are required to implement social distancing. As well as economically, which has an impact on some MSMEs and large companies. According to data on September 11, 2020 in the local government of Banjaran District, Bandung Regency, West Java, there were three people tested positive, and three people were suspected. This is very worrying, considering that one of the right rooms for many people to enter is public transportation. When the new normal phase was implemented, city transportation in Banjaran was still filled with people passing by without strict health protocols due to the lack of socialization and supervision of city transportation in the area. So it is necessary to have an automatic system that can make it easier for drivers to control the number of passengers on public transportation. The system is made using the help of an ultrasonic sensor and a buzzer. This buzzer will sound like an alarm if the number of passengers in public transportation exceeds a predetermined capacity. The hope is that this tool can be an effective solution to reduce the spread of Covid-19, especially on public transportation.
\end{abstract}

Keywords: social distancing; new normal; ultrasonic; buzzer

\begin{abstract}
Abstrak
Salah satu masalah saat ini di dunia adalah pademi covid-19. Tak terkecuali di Indonesia yang ikut terkena dampak dari virus tersebut baik secara sosial, yaitu kita diharuskan menerapkan sosial distancing. Maupun secara ekonomi, yang berdampak terhadap sebagian kalangan UMKM maupun perusahaan besar. Menurut data pada tanggal 11 September 2020 di pemerintah setempat Kecamatan Banjaran, Kabupaten Bandung, Jawa Barat terdapat tiga orang dinyatakan positif, dan tiga orang suspek. Hal ini sangat menghawatirkan, mengingat salah satu ruangan yang tepat dimasuki banyak orang adalah angkutan umum, ketika fase new normal diberlakukan, angkutan kota di Banjaran masih dipenuhi oleh lalu-lalang masyarakat tanpa protokol kesehatan yang ketat karena kurangnya sosialisasi dan pengawasan angkutan kota di daerah tersebut ehingga perlu adanya sistem otomatis yang dapat
\end{abstract}


Mochamad Ravi Adia Pramesti, Muhamad Rafi Abdul Rasyd, Refki Rizki Alfani, Muharammi Dzaki Pasya Sundava, Ghita Putrie Ghantina dan Muhammad Hasbi Ash

Shiddieqy

memudahkan pengendara dalam mengontrol jumlah penumpang pada transportasi umum. Sistem tersebut dibuat dengan menggunakan bantuan sensor ultrasonic dan buzzer. Buzzer ini akan berbunyi seperti alarm jika jumlah penumpang dalam angkutan umum melebihi kapasitas yang telah ditentukan. Harapannya, dengan adanya alat tersebut dapat menjadi solusi yang efektif untuk menekan penyebaran covid-19 terutama di angkutan umum.

Kata Kunci: sosial distancing; new normal; ultrasonic; buzzer.

\section{Pendahuluan}

Uji coba teknologi yang kami ciptakan akan menyasar angkutan kota di rute Banjaran-Cikalong. Rute ini terpusat di terminal banjaran yang berada di Kecamatan Banjaran, Kabupaten Bandung. Banjaran merupakan wilayah yang majemuk. Di Banjaran, terdapat kurang lebih 158 ribu penduduk, dengan rata-rata penduduknya berpenghasilan sebagai buruh, baik tani maupun industri. Berdasarkan sumber, jumlah buruh tani mencapai 6265 jiwa dan buruh industri 18644 jiwa (Statistik Kecamatan Banjaran, 2018).

Padatnya penduduk di Desa Banjaran, menjadikan Banjaran sebagai tempat yang beresiko tinggi akan penularan virus. Update 11 September kemarin, terdapat tiga orang dinyatakan positif, dan tiga orang suspek.

Banyaknya warga banjaran yang masih kurang kesadarannya terhadap penerapan protokol kesehatan, ditenggarai menjadi polemik tersendiri untuk menerapkan kebijakan pembatasan penumpang angkutan dalam rangka memutus rantai penularan virus. Sehingga, ketika fase new normal diberlakukan, angkutan kota di Banjaran masih dipenuhi oleh lalu-lalang masyarakat tanpa protokol kesehatan yang ketat karena kurangnya sosialisasi dan pengawasan angkutan desa di daerah tersebut.

1. Geografi

Keadaan geografi Kecamatan Banjaran Kabupaten Bandung merupakan kecamatan dengan pemukiman padat karena berdekatan dengan pasar, adanya alun-alun kecamatan, serta pusat lembaga pendidikan.

2. Persebaran penduduk dan mata pencaharian

Orang banjaran didominasi lulusan SMP yang mencapai 19.375 jiwa, lulusan SD mencapai 15.102 jiwa, sisanya 6265 tidak lulus sekolah. Mata pencaharian penduduk di dominasi buruh industri dan buruh tani. Dengan penghasilan rata-rata Rp3.000.000 - Rp4.000.000 ( Koordinator Statistik, 2018).

3. Permasalahan dengan adanya kasus positif yang lumayan banyak, yakni mencapai 3 orang positif dan 3 orang suspek, Banjaran dinyatakan sebagai daerah zona merah di Kabupaten Bandung. Meskipun begitu, masih banyak masyarakat yang tidak taat akan aturan dan supir angkutan kota yang melanggar kebijakan pembatasan penumpang di angkot. Padahal klaster transportasi umum dianggap sebagai klaster paling potensial dalam penyebaran virus (Susantono, 2014). Untuk itu, kami bekerja sama dengan mitra komunitas supir pengemudi angkutan umum di Kecamatan Banjaran, Kabupaten Bandung. Komunitas ini bukan komunitas berbadan hukum bercap resmi, hanya kumpulan pengemudi yang memang peduli terhadap kondisi kesehatan penumpangnya (Tirachini \& Cats, 2020).

Peneliti merasa perlu untuk menyelesaikan permasalahan yang ada tentang pengawasan kapasitas penumpang di angkutan kota di rute Banjaran-Cikalong dengan menciptakan sistem otomatis yang dapat memudahkan pengendara dalam mengontrol 
jumlah penumpang pada transportasi umum. Sistem tersebut dibuat dengan menggunakan bantuan sensor Ultrasonic dan BuzzeBuzzer ini akan berbunyi seperti alarm jika jumlah penumpang dalam angkutan umum melebihi kapasitas yang telah ditentukan dan jumlah penumpang yang ada pada angkutan umum akan ditampilkan melalui LCD yang di pasang sebelum pintu masuk angkutan umum (Nurjanah, 2019).

\section{Metode Penelitian}

Metode penelitian pada pelaksanaan Program Kreativitas Mahasiswa (PKMM) ini menggunakan metode penelitian kualitatif dimana proses dan perspektif subjek lebih ditonjolkan. Adapun beberapa proses atau tahap pelaksanaan kegiatan terdiri dari :

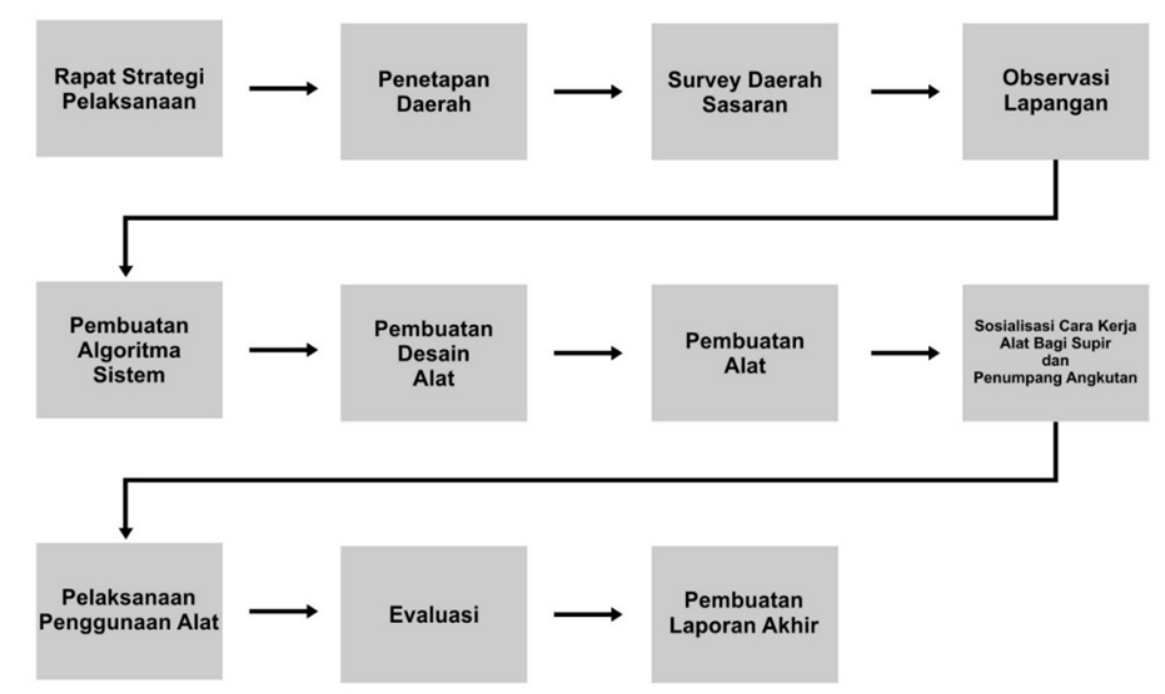

Gambar 1. Tahapan Pelaksanaan Kegiatan Program Masyarakat

\section{Perencanaan Kegiatan}

Pada tahap ini beberapa hal yang dilakukan, yaitu:

a. Rapat Strategi Pelaksanaan: Tahap ini sudah dilakukan dimana menentukan pembagian tugas setiap anggota kelompok sebelum pelaksanaan kegiatan pengabdian dilakukan.

b. Penetapan Daerah Sasaran: Melakukan pencarian dan menetapkan daerah sasaran melalui jejaring internet dan melakukan pengumpulan data dengan wawancara secara daring dengan mitra yang berada di daerah sasaran yang sudah ditentukan sebelumnya.

c. Observasi Lapangan: Meninjau keadaan dan permasalahan daerah sasaran yang telah ditentukan serta mencari mitra sebagai penerima pelaksanaan pengabdian yang telah dirancang dan membuat kesepakatan dilakukan oleh dua orang perwakilan kelompok (Nawawi \& Hakiem, 2018).

Tahap Pelaksanaa Kegiatan

a. Pembuatan Algoritma Sistem: Membuat algoritma cara kerja sistem yang akan digunakan di angkutan umum sebagai penunjang protokol kesehatan. 
Mochamad Ravi Adia Pramesti, Muhamad Rafi Abdul Rasyd, Refki Rizki Alfani, Muharammi Dzaki Pasya Sundava, Ghita Putrie Ghantina dan Muhammad Hasbi Ash

Shiddieqy

b. Perancangan Desain Alat Sistem Monitoring dan Alarm Jumlah Penumpang: Merancang desain alat yang sesuai dengan perencanaan awal.

c. Pembuatan Alat: Membuat alat berdasarkan desain dan algoritma yang telah dirancang dan dikerjakan oleh seluruh anggota kelompok dengan cara membagibagi tugas kemudian digabungkan.

d. Sosialisasi Alat: Mensosialisasikan fungsi dan cara kerja alat yang telah dibuat kepada pengemudi dan penumpang angkutan umum dari mitra yang telah ditentukan.

e. Pelaksanaan Penggunaan Alat: Menerapkan alat pada angkutan umum dari mitra yang telah ditentukan (Djuandi, 2011).

Tahap Pasca Kegiatan

a. Evaluasi

Mengevaluasi hasil pelaksanaan pengabdian yang telah dilaksanakan.

b. Analisa dan kesimpulan menganalisa dan menyimpulkan hasil dari evaluasi yang telah ditentukan.

c. Pembuatan Laporan

Membuat laporan hasil pelaksanaan kegiatan pengabdian.

\section{Hasil dan Pembahasan}

Ditengah masalah kurangnya kesadaran masyarakat terhadap penerapan protokol kesehatan di tengah pandemi covid-19 ini, kami membuat sistem otomatis untuk membantu memudahkan pengendara angkutan umum rute Banjaran-Cikalong dalam mengontrol jumlah penumpang. Setelah Sistem Monitoring dan Alarm Jumlah Penumpang untuk Angkutan Umum ini selesai, karena situasi sedang covid-19, membuat kami tidak memungkinkan untuk menguji coba alat langsung kepada mitra kami, yaitu komunitas angkutan kota rute Banjaran-Cikalong. Sebagai solusi dari masalah tersebut, kami membuat poster dan video mengenai sistem (Fitriani, Maulidya, Salafudzin, Izza, \& Assyaefi, n.d.). Dalam bentuk poster dan video yang berisi mengenai kegunaan dan cara kerja sistem ketika dipakai.

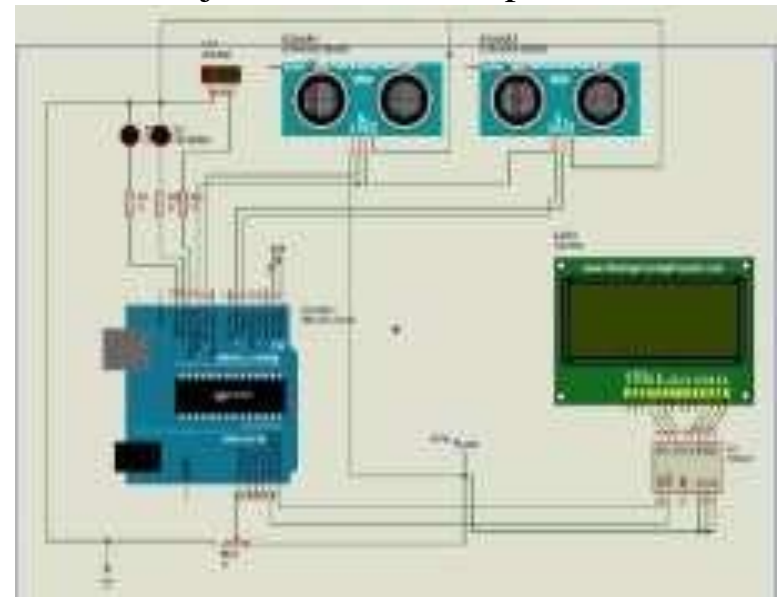

Gambar 2. Wiring Diagram alat

Pembuatan prototipe alat dilakukan dengan menggunakan rancangan wiring diagram seperti gambar 2, digunakan 2 sensor ultrasonics untuk mendeteksi orang yang masuk dan keluar (Ningrum \& Hasyim, 2017). Cara kerja sistem ini sensor ditempatkan 
pada pintu masuk, cara kerja alat tersebut, yaitu menset jumlah penumpang/ pengunjung maksimal yang kita inginkan menggunakan potensiometer setiap pengunjung/penumpang yang masuk melalui pintu masuk tersebut akan dibaca oleh sensor dan jumlah penumpang/pengunjung akan bertambah, jika penumpang/pengunjung keluar melalui pintu yang sama akan dibaca juga oleh sensor dan jumlah penumpang atau pengunjung akan dikurangi, ketika jumlah penumpang pengunjung melebihi batas maksimal alarm akan menyala (Susaptoyono, 2012).

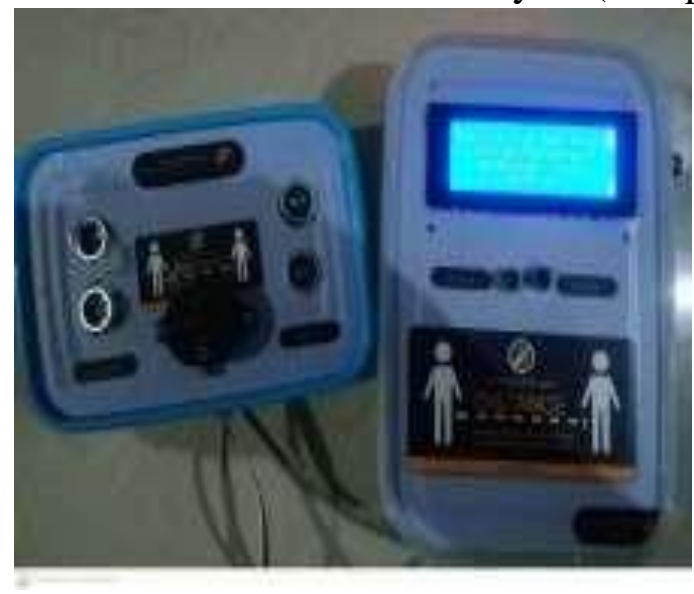

Gambar 3. Hasil prototipe alat

Kotak yang pertama difungsikan sebagai sensor yang akan ditempatkan di pintu masuk untuk mendeteksi setiap orang yang masuk maupun keluar, kotak selanjutnya sebagai interface dan juga kontroller pada layer LCD ditampilkan berapa jumlah orang saat ini yang berada di dalam angkuan umum, bus atau pada suatu ruangan (Syafril, n.d.).

Ditampilkan juga jumlah maksimum penumpang/pengunjungnya sehingga jika melebih maksimum alarm akan menyala (Scaramuzzino \& Scaramuzzino, 2017). Demikian sistem ini dibuat agar dapat berfungsi sebagai alarm jumlah penumpang atau pengunjung suatu transfortasi umum atau suatu tempat dan sebagai sistem monitoring jumlah penumpang yang berada saat itu (Yuliana \& Saptono, 2017).

Potensi keberlanjutan dalam bidang sosial program pengabdian yang telah dibuat yaitu Sistem Monitoring dan Alarm Jumlah Penumpang pada Angkutan umum, sebagai berikut:

a. Membuat masyarakat merasa lebih aman menaiki angkutan umum.

b. Membuat masyarakat menjadi lebih patuh terhadap protokol kesehatan.

c. Membantu pengendara dalam mengontrol jumlah penumpang.

d. Mengurangi resiko penyebaran virus covid-19.

e. Sebagai acuan dan refrensi dalam pengembangan topic serupa dan mengembangkan lebih lanjut.

\section{Kesimpulan}

Berdasarkan hasil wawancara dan terselenggaranya PKM secara langsung kepada masyarakat sasaran yang dilakukan peneliti yaitu pengemudi dan penumpang angkutan kota rute Banjaran-Cikalong, Kabupaten Bandung, kesimpulannya adalah penghasilan pengemudi memang mengalami penurunan yang cukup besar semenjak pandemi, yaitu dari total laba bersih penghasilan yang didapat pengemudi biasanya 
Mochamad Ravi Adia Pramesti, Muhamad Rafi Abdul Rasyd, Refki Rizki Alfani, Muharammi Dzaki Pasya Sundava, Ghita Putrie Ghantina dan Muhammad Hasbi Ash

Shiddieqy

sebesar kurang-lebih seratus ribu rupiah mengalami penurunan menjadi hanya sebesar kurang lebih dua puluh ribu rupiah. Hal ini dikarenakan penumpang yang biasa menaiki angkutan kota rute tersebut sebelum pandemi didominasi oleh pelajar, ibu-ibu yang beraktivitas seperti pergi ke pasar, dan pegawai buruh, tetapi semenjak pandemi yang menaiki angkutan kota hanya ada ibu-ibu dan pegawai buruh, yang dimana pelajar tidak lagi menaiki angkutan kota karena sekolah yang dilaksanakan dari rumah.

Dari sisi pengemudi mereka sebenarnya tidak setuju dengan diadakannya pembatasan penumpang, karena fokus mereka yang utama dari sisi ekonomi yaitu mencari penumpang sebanyak mungkin agar target setoran tercapai dan laba bersih mereka besar, akan tetapi dari sisi penumpang yang peneliti wawancarai mereka setuju karena berpikir bahwa pandemi Covid-19 ini berbahaya, terutama penumpang ibu-ibu yang membawa anaknya menaiki angkutan kota. Maka walaupun dari sisi pengemudi menolak diadakannya pembatasan penumpang dengan menerapkan sistem monitoring dan alarm jumlah penumpang ini, tetapi dari sisi penumpang mereka setuju, karena jika pengemudi tidak memerhatikan social distancing dan protokol kesehatan yang ditetapkan pemerintah lainnya maka pengemudi pun mengalami kerugian. Kerugiannya yaitu tidak adanya penumpang yang menaiki angkutan kota rute tersebut dengan alasan takut, sehingga pada akhirnya pengemudi pun setuju dengan diselenggarakannya PKM ini.

Semua program ini yaitu PKM-M diselenggarakan sebagai upaya dalam meningkatkan rasa kewaspadaan akan bahaya Covid-19 dan juga sebagai upaya pelaksanaan protokol kesehatan dalam angkutan kota. Dengan berbagai rangkaian kegiatan yang telah dilalui, program tersebut terlaksana sesuai dengan rancangan yang telah dibuat sebelumnya. Namun masih terdapat evaluasi-evaluasi yang harus kami tingkatkan dalam beberapa hal.

Selanjutnya, dengan adanya program ini harapannya menjadi pemantik bagi setiap organisasi yang bergerak dalam lingkup transportasi umum untuk selalu menjaga protokol kesehatan. Nantinya bisa menjadi program berintegrasi dari pemerintah dan juga organisasi-organisasi yang menaungi kegiatan transportasi umum. Bahkan tidak hanya dalam transportasi umum, program ini dapat dilaksanakan di tempat lain seperti ruangan kantor dan tempat tertutup lainnya. 


\section{Bibliografi}

Djuandi, Feri. (2011). Pengenalan arduino. E-Book. Www. Tobuku, 24.

Fitriani, Avisha, Maulidya, Ikliliya Zahwa, Salafudzin, Ahmad, Izza, Nurul Baeti, \& Assyaefi, Moh Izza. (n.d.). ED. COFID (EDUCATION COVID-19 FOR KIDS) DALAM RANGKA PENCEGAHAN PENYEBARAN VIRUS COVID-19 KEPADA ANAK-ANAK SEKOLAH DASAR DI DESA WONOREJO KARANGANYAR DEMAK.

Nawawi, M. Kholil, \& Hakiem, Hilman. (2018). Strategi Pemasaran Funding Officer Dalam Meningkatkan Minat Nasabah Di BPRS Amanah Ummah. Al-Infaq: Jurnal Ekonomi Islam, 6(2), 379-429.

Ningrum, Prahita Ratna, \& Hasyim, Asy'ari. (2017). Perancangan Prototype Kendali Kapasitas Area Parkir Dengan Karakteristik Dua Sensor Berbasis PLC. Universitas Muhammadiyah Surakarta.

Nurjanah, Revina. (2019). Pembangunan Aplikasi Pembayaran Tiket Bus Damri Berbasis Android Melalui Payment Online. Universitas Komputer Indonesia.

Scaramuzzino, Gabriella, \& Scaramuzzino, Roberto. (2017). The weapon of a new generation?-Swedish Civil Society Organizations' use of social media to influence politics. Journal of Information Technology \& Politics, 14(1), 46-61.

Statistik, Koordinator Kecamatan Banjaran. (2018). Kecamatan Banjaran.

Susantono, Bambang. (2014). Revolusi Transportasi. Gramedia Pustaka Utama.

Susaptoyono, Yogyo. (2012). Bluetooth. Yogyakarta: Cv. Andi Offsed.

Syafril, Syafrimen. (n.d.). MASTER PLAN INFORMATION \& COMMUNICATION TECHNOLOGY (ICT) "MENUJU SMART UNIVERSITY UIN RADEN INTAN LAMPUNG."

Tirachini, Alejandro, \& Cats, Oded. (2020). COVID-19 and public transportation: Current assessment, prospects, and research needs. Journal of Public Transportation, 22(1), 1.

Yuliana, Khozin, \& Saptono, Saptono. (2017). Prototype Pengontrolan Penghitung Jumlah Calon Penumpang Angkutan Umum Pada Dinas Perhubungan Kota Tangerang Berbasis Arduino Uno. JURNAL SISFOTEK GLOBAL, 7(2). 